\title{
THE LANHAM ACT AND INTERNATIONAL TRADE
}

\author{
StEPHEN P. LADAs*
}

I

International trade is inconceivable today without trade-marks and their adequate protection. Merchandise is sold by brands in foreign markets even more than in the domestic market. In the domestic market, the purchasing public has additional ways of identifying products: knowledge of the manufacturer or merchant by reputation, by newspaper, magazine or radio advertising, by personal visit to the factory or store, by community experience, and the like. In foreign markets, trade-marks are the only means of creating and maintaining good will with a foreign public.

More than one hundred years ago, nations began stipulating for reciprocal protection of trade-marks as an adjunct to treaties of commerce. Later special agreements were concluded. Lastly, it was recognized that bipartite treaties were not sufficient since the problem was not that of protection of trade-marks as between two nations only, but rather a problem of legislation on an international level which would establish as far as possible a uniform system for the protection of trade-marks everywhere.

At one time-at the Congress on Industrial Property at Paris in $1878-$ it was proposed that a uniform law be adopted by all nations. This proposal was promptly abandoned when it was observed by the French jurist, Lyon Caen, that:

We cannot hope, in the present state of things, that we could have in all the countries laws on industrial property which would be common on all points. It is an utopia ... What makes impossible the adoption of uniform laws in all the countries on this subject is that these laws are closely related to the civil law, civil procedure, commercial law, penal law and penal procedure of each country. It would have to be necessary to make uniform all these branches of legislation in order to have uniform laws on industrial property and this is not possible.

What the Congress did then was to seek an agreement on certain problems of international protection of industrial property, and to recommend an international convention the stipulations of which would require the domestic legislation of the contracting countries to yield or to be revised. We know that this recommendation was followed and that an International Convention for the Protection of Industrial Property was entered into in 1883 . This convention by successive revisions

- IL.D. I919, Athens, Greece; A.M. 1923, School of Political Science, Paris; LL.B. 1926, S.J.D. 1927, Harvard University. Member of firm of Langner, Parry, Card \& Langner, New York. Author: The Internatronal Protection of Trade-Marks by the American Republics (r929); The International Protection of Industrial Property (i930); The Exchange of Minorities: Bulgaria, Greece and Turkey (1932); The International Prottemton of Literary and Arttstic Property (i939). 
has extended the scope of its stipulations so as to cover a broader field of international legislation on the subject of industrial property, so that at this time it may be truly said that industrial property, and trade-marks in particular, are governed by a twofold legal régime: national legisaltion of each country and the international legislation embodied in this convention.

The International Convention as last revised at London in 1934 extends today to forty-seven countries, including practically all of Europe (with the exception of Soviet Russia), the British Dominions, the French, Dutch, Portuguese, and Spanish colonies, and five American republics: Brazil, Cuba, the Dominican Republic, Mexico, and the United States.

On the other hand, there has been a distinct effort at inter-American legislation on trade-marks among the American Republics. Here the system followed was not the adoption of a convention with successive revisions but rather the adoption of a series of successive conventions: in $1902,1906,1910,1923$, and 1929. The latest and most satisfactory convention is the one adopted at Washington on February 20, 1929, which has detailed provisions on the inter-American protection of trade-marks, trade names, and indications of origin, and on the suppression of unfair competition. However, this convention has been ratified by only ten of the twenty-one republics: Colombia, Cuba, Guatemala, Haiti, Honduras, Nicaragua, Panama, Paraguay, Peru, and the United States.

\section{II}

Prior to the adoption of the Lanham Act, our federal trade-mark legislation did not accord, in several respects, with the stipulations of the international or Pan American conventions. The Patent Office, following an old opinion of the AttorneyGeneral, applied the Act of $1905^{1}$ rather than the convention wherever there was a conflict between the two. The decisions of the courts on the same issue were at least inconclusive, and the dominant opinion was that the convention was not selfexecuting and that enabling legislation was required to make its stipulations mandatory. The decision of the Supreme Court in Bacardi v. Domenech ${ }^{2}$ in 1940 was the first clear judicial pronouncement that the conventions were self-executing and should be given effect regardless of domestic legislation.

One of the most interesting features of the Lanham Act is that it contains a special title-Title 9-captioned International Conventions. ${ }^{3}$ The inclusion of such a title in the Act is due to Edward S. Rogers, whose passing is so deeply regretted by all of us. At his suggestion, these provisions were prepared with a view to carrying out as fully as possible the commitments of our country under international conventions for the protection of trade-marks and trade names and for the suppression of unfair competition.

The Act itself specifies as one of its purposes "to carry out the provisions of cer-

${ }^{1} 33$ StaT. 724 (1905), 15 U. S. C. \$\$ 8I-I09 (1946).

23 II U. S. 150 (1940).

${ }^{3} 60$ STAT. 44 I, 15 U. S. C. \$1126 (1946). 
tain international conventions," and the last words of Section 45 state that the intention of the Act is "to provide rights and remedies stipulated by treaties and conventions respecting trade-marks, trade names and unfair competition entered into between the United States and foreign nations."

The Lanham Act may be considered from two points of view: how far its provisions actually carry out the stipulations of international conventions, and by what means they do so; and secondly, how far it operates in facilitating the international trade of United States trade-mark owners.

The first inquiry calls for an exposition of the provisions of Title 9 in their relation to the stipulations of International Conventions. Title 9 consists of Section 44, divided into nine paragraphs.

\section{Special Register for International Marks}

We may dismiss subsection (a) with a brief remark. This provides for a special register, which apparently is neither the principal nor the supplemental register, of all marks communicated to the Patent Office by international bureaus. In as much as the United States is not a party to the Madrid Arrangement for the International Registration of Trade-Marks, and we denounced the Protocol for Inter-American Registration of Trade-Marks on September 29, 1945, this provision of the Lanham Act seems to look to possible future developments, and has no present application.

\section{General Principles of Protection of Foreigners}

a. Persons entitled to benefits. Section 44 (b) provides that certain persons defined therein shall be entitled to certain rights. These persons are nationals of, domiciled in, or having a bona fide or effective business or commercial establishment in any foreign country which is a party to the International Convention, the Pan American Convention, or "any other Convention or Treaty relating to trade-marks, etc." to which the United States is a party. The only question raising any problem of interpretation herein is, What does the word "relate" mean with respect to conventions or treaties other than the International Convention and the Pan American Convention? Does this include treaties which contain provisions for the protection of trade-marks and trade names, and for the suppression of unfair competition, while they relate generally to other subjects? Take, for instance, the Treaty of Friendship, Commerce and Navigation with China, signed November 4, r946. This includes Article IX on the Protection of Industrial Property. It stipulates that both countries shall grant effective protection to trade-marks and trade names and against acts of unfair competition. It would seem that this treaty is one "relating" to trademarks, trade names and unfair competition within the meaning of subsection (b).

It should be noted that subsection (b) extends the benefits of the section only to the persons defined therein. How about other foreigners? Suppose a national of Chile (which is not a party to any convention relating to trade-marks with the United States) applies for registration of a mark. He cannot obtain registration based only

'60 STAT. 443,15 U. S. C. $\$$ Y127 (1946). 
on his Chilean registration. He must allege use in commerce, as any United States applicant, under the general provisions of the Act, since Section 44 is not applicable to him.

b. National treatment and special rights under conventions. Subsection (b) enacts the general rule that persons entitled to the benefits of certain conventions "shall be entitled to the benefits and subject to the provisions of the Act to the extent and under the conditions essential to give effect to such Conventions." And then follows the provision: "except as provided in the following paragraphs of this section." At this point it is particularly important to recall that the International Convention, as well as the Pan American Convention, contains two fundamental principles on this subject matter:

(I) The so-called "national treatment" principle, under which a foreigner is entitled to the same protection as a national trade-mark owner, subject to complying with the provisions and requirements imposed on nationals; and

(2) The so-called "convention rights" principle, under which a foreigner enjoys, in addition, certain rights or benefits specifically provided for by the convention which may involve a derogation from the national law.

It is these convention rights that are described as "exceptions" in the final sentence in subsection (b) and are covered by the subsequent subsections of Section 44. These will be discussed hereafter, but we should not lose sight of the fact that under subsection (b) the object is to give to the persons entitled to claim under the conventions all the benefits of the Lanham Act, subject to its provisions, and also to give such benefits "to the extent and under the conditions essential to give effect to any such conventions."

This phrase means particularly two things:

(I) If a certain convention does not provide for a specific benefit-for instance, the right of priority-the foreign applicant need not be given such right. Take, for instance, the treaty with China which has been referred to. This does not contain a provision for a right of priority in favor of an applicant based on his prior application in his home country. We are not required, it seems to me, to grant a right of priority to a Chinese applicant, since this would be beyond the extent required to give effect to such treaty. The same is true of applicants from countries party to the Inter-American Convention of 1929 , which does not contain provisions on a right of priority.

(2) In considering the position of a foreign trade-mark owner claiming the benefits of the International Convention or the Inter-American Convention, we must always lean to that interpretation of the provisions of the Act which will give effect to the stipulations of the convention, since the definite object of the Act is to give effect to the conventions.

c. Requirement of foreign registration. Subsection (c) provides that no registration of a mark in the United States by a person described in subsection (b) shall be 
granted if such mark has not been registered in the country of origin of the applicant unless the applicant alleges use in commerce. Thus, while the Act requires use in commerce of all United States applicants before an application may be filed, foreign applicants may register without alleging use in commerce, but in such case they must produce a certified copy of registration in their home country. The production of a home certificate is not a requirement under the convention, but such interpretation has been given to the convention by a number of foreign countries, and in any case, in several foreign countries, particularly in most of Europe, Americans are required to produce a certified copy of home registration. Generally this is not a requirement for all foreign applicants, but a requirement of reciprocity; in other words, it is because we require foreign applicants to show that they have a home registration that these countries require the same of American applicants.

\section{Right of Priority}

This is one of the special rights provided by the convention which is given effect by subsection (d) of Section 44. A foreign applicant who files in his country of origin may, within six months, file for the same mark in the United States and will be given the benefit of his foreign filing date. No difference appears to exist between the convention's stipulation and the provision of subsection (d). The subsection does not explicitly require the filing of a certified copy of the foreign application, but in view of subsection (c) this is certainly to be filed. Rule 7 (9) of the Patent Office provides that the certified copy must be filed before registration is granted in the United States, and, so long as it is not filed, registration will not be granted.

Suppose the foreign application, on which the right of priority is based, is ultimately rejected. What becomes of the United States application? In view of subsection (c), the mark cannot be registered in the United States. The only course of action possible for the applicant is to abandon the application and file a new one alleging use in commerce, in which case he may register without the benefit of home registration.

\section{Registrability of Foreign Marks on Principal or Supplemental Register}

Article 6 of the International Convention provides for the so-called "validation" of trade-marks registered in the country of origin. That is, a mark which is registered in the country of origin, the article says, must be accepted for registration in the other countries party thereto "as is" (telle quelle), subject to the exceptions enumerated in Article 6. Subsection (e) of Section 44 purports to carry out this stipulation of Article 6. It provides that a mark, duly registered in the country of origin of the foreign applicant, may be registered on the principal register, if eligible, otherwise on the supplemental register. Subsection (e) does not deal with the exceptions of Article 6 of the International Convention. What are these exceptions? Registration may be denied of the following:

a. Marks which infringe rights of third parties; 
b. Marks contrary to morality or public order;

c. Marks having no distinctive character and which are deemed to be of two kinds:

(I) descriptive or geographical terms;

(2) terms which have become common in the current language or trade.

Exception (a) is provided for in subsection (d) of Section $2^{5}$ of the Act. Exception (b) is covered in subsection (a) of Section 2. Exception (c) is covered by subsection (e) of Section 2.

It will be noted, however, that while surnames are not excluded by Article 6 of the Convention, they are unregistrable under Section 2, subsection (e) of the Act. Also, it will be recalled that registration on the principal register under Section 2 is limited to a "trade mark," and under the definition of Section 45, a trademark includes "any word, name, symbol or device or any combination thereof." The question arises whether a distinctive package or container used to identify and distinguish the goods of a manufacturer from those of others is a "device" under this definition and therefore registrable on the principal register. Opinion appears to be divided on this point. A device may be broadly construed as including, as Webster says, "anything ingeniously and fancifully designed" to identify and distinguish the product of a manufacturer, and an original or distinctive container may be that. If the opposite should be maintained, then we have another case, in addition to surnames, where a foreign applicant may have a registration of a distinctive container in his own country and requires a registration in the United States Patent Office.

It may then be maintained that if it is a question of carrying out a stipulation of the Convention, the answer is not whether or not our Act prohibits such registration. The precise issue came up a few years ago in Austria, where under the law bottles are not registrable as trade-marks, and the Patent Office refused registration of a French trade-mark consisting in a distinctive liquor bottle on this ground. On appeal, the Supreme Administrative Tribunal of Austria had this to say:

It is a juridical error to ask, in considering whether a mark or sign registered as a trade mark in a country of the Union should be protected in Austria, whether such mark or sign may be a trade mark according to the Austrian law and to permit international law to interfere only if the answer is in the affirmative. It is one of the bases of the International regulation not to let each state examine, according to its own law, the character of a trade mark. The Convention of Union contains an international regulation of trade marks complete in itself, forming an independent whole, to which the national law of each country of the Union must yield, and according to which the law of the country of origin is decisive on the question of the things which may be used as trade marks.

This decision is referred to in order to indicate what the effect of the stipulation of Article 6 of the Convention is: the object was to internationalize, so to speak, the status of a trade-mark, to validate such marks throughout the Union, subject to the three exceptions mentioned previously. In other words, it is stipulated in the Con-

${ }^{5} 60$ STAT. 428,15 U. S. C. \$1052(d) (1946). 
vention that when a foreign trade-mark owner comes to another country with a registration in his home country for his trade mark, and such mark is not contrary to morality and public order; if it does not infringe prior rights in the country where he seeks registration and protection; if it is not descriptive or geographical and is not common to the trade-then the foreign mark must be granted registration and protection although it is a trade-mark which, by virtue of a certain definition of marks in the country in question, would not be ordinarily registered and protected. There is an abundance of decisions in countries party to the Convention enforcing this stipulation. And what is the reason for this stipulation? Simply a recognition of the international character of a trade-mark. It was thought that once a person had adopted and registered a trade-mark in his home country, and built up his good will around such mark, and carried on international trade under such mark, he should not be compelled to adopt a different mark for each country to comply with such country's conception of what a trade-mark is so long as third parties' rights therein are not infringed, so long as public order is not affected, and so long as the freedom of trade and industry is not restrained by monopolizing something which is commonly used in such trade or industry.

The Lanham Act, recognizing the fact that the United States is required under Article 6 of the Convention to admit to registration and protection marks registered in other countries of the Union, provides that such marks may be registered on the principal register, if eligible, otherwise on the supplemental register. If we should lean to a narrow interpretation of the definition of trade-marks registrable on the principal register, so that the words "symbol or device" may not include a distinctive package, we must then consider whether the stipulation of the Convention is carried out when such marks, surnames, containers, etc., are refused registration on the principal register but are granted registration on the supplemental register. Before answering this question, let us remember that Article 6 of the Convention stipulates that a mark duly registered in the country of origin of the applicant shall ( $I$ ) be admitted to registration and (2) protected in the other countries. This raises immediately the question: Is a trade-mark registered on the supplemental register protected in the United States within the meaning of the Convention?

In this connection, it will be recalled that marks on the supplemental register are deprived of important attributes of a trade-mark on the principal register:

a. They do not become incontestable under Section $15{ }^{6}$

b. They are not constructive notice under Section $22^{7}$

c. They do not create a presumption of validity or ownership under Section $33^{8}$

d. They may not, of themselves, form the basis of an opposition or cancellation under Sections 13 and $14^{\circ}{ }^{\circ}$

${ }^{\circ} 60$ STAT. 433 , 15 U. S. C. \$1065 (1946).

'60 STAT. 435 , I5 U. S. C. \$1072 (1946).

${ }^{8} 60$ StAT. 438 , 15 U. S. C. \$1115 (1946).

- 6o Stat. 433, I5 U. S. C. \$\$1063, 1064 (I946). 
e. They may not be used to stop importation of infringing merchandise under Section 28.10

However, marks on the supplemental register enjoy the following attributes:

a. They may be cited by the Patent Office, I assume, as registered trade-marks under Section 2(d) (since this refers to a "mark" registered in the Patent Office and not a "trade-mark"). However, no interference is declared under Section $16 .{ }^{11}$

b. They enjoy the remedies against infringement under Section $32^{12}$

c. They may be licensed under Section $5^{13}$ and assigned under Section I0. ${ }^{14}$

d. They can use the notice of registration provided for in Section $29{ }^{15}$ at least as I interpret this section. In other words, marking is not mandatory but is permissive.

e. And particularly they may, as I shall attempt to argue later here, be registered subsequently on the principal register.

Does this condition indicate that the marks are protected when registered on the supplemental register?

If they are not, two conclusions may have to follow:

a. Foreign countries may refuse to register American trade-marks based on registrations in the United States obtained on the supplemental register, on the ground that Article 6 of the Convention does not apply to such registrations.

b. Foreign applicants, coming to the United States with a registration in their own country, may refuse to accept registration on the supplemental register and insist on registration on the principal register, since under Article 6 of the Convention the foreign registered trade-mark must be not only admitted to registration but also protected in the United States.

Section 23 specifically provides for registration on the supplemental register of marks which are "capable of distinguishing the applicant's goods or services."10 Note that under the Act of $1920^{17}$ there was no requirement that the mark must be capable of distinguishing; all marks not registrable under the Act of 1905 and in bona fide use for not less than a year could be registered under the Act of rg20. Indeed, the notion of "capable of distinguishing" is a new notion under our law, and we may wish to explore it somewhat by referring to the British law. Indeed, this is an expression used in the British Trade Marks $\mathrm{Act}^{18}$ as a requirement for registration in Part B of the Register in Great Britain: “. . . it must be capable, in relation to the goods in respect of which it is registered or proposed to be registered, of distinguishing ..." Section Io of the British Act of 1938 further provides:

In determining whether a trade mark is capable of distinguishing as aforesaid the tribunal may have regard to the, extent to which-

${ }^{10} 60$ Stat. 436 , 15 U. S. C. \$1096 (1946).

${ }^{12} 6$ O STAT. 437 , 15 U. S. C. \$III4 (1946).

I* 6o. Stat. 43I, 15 U. S. C. §то6o (1946).

1160 STAT. 434,15 U. S. C. $\$ 1066$ (1946).

${ }^{18} 60$ STAT. 429, 15 U. S. C. \$1055 (1946).

${ }^{10}$ 6o STAT. 435 , I5 U. S. C. \$rogi (I946).

${ }^{25} 60$ STAT. 436 , X5 U. S. C. SIIII (1946).

${ }^{17} 4$ I STAT. 533-535 (1920), I5 U. S. C. \$\$12I-128 (1946).

${ }^{28}$ Trade Marks Act, 1938, I \& 2 Geo. VI, c. 22. 
(a) the trade mark is inherently capable of distinguishing as aforesaid; and

(b) by reason of the use of the trade mark or of any other circumstances, the trade mark is in fact capable of distinguishing . . .19

The Patent Office and the courts in England have developed quite definite standards of registrability in Part B, and a mark which is descriptive or geographical, or a surname, is not admitted to registration in Part B without some persuasive showing that the mark is capable of distinguishing the goods of the applicant.

It is true that we cannot be guided by these standards generally because the English statute does not contain a separate definition of trade-marks registrable in Part $B$ as our Act does for registrations on the supplemental register; but it is also true that registrations in Part $B$ of the register do not become incontestable in England, nor does a registration in Part B grant a prima facie exclusive right to use, and it is always open to a defendant to establish that the use of which the plaintiff complains is not likely to deceive the public as to origin-which is similar to the position in a passing-off action.

Yet, because of the conservative attitude of British tribunals in granting registrations in Part B of the register, registrations are protected fairly well against infringements.

Attention may be directed in this connection to the decision of the High Court of Justice in the case of Bale \& Church Ltd. $v$. Sutton, Parsons \& Sutton. ${ }^{20}$ The plaintiff in that case had registered the trade-mark "Kleenoff" in Part B of the Register in respect of a cleaning compound, and the defendant began using the trademark "Kleenup." The lower court and the Court of Appeals found for the plaintiff. It was conceded that registration in Part B- of the register did not prevent the defendant from challenging the validity of the registration, but the court held that unless the exclusive right of the plaintiff in the Part B registration is challenged, the test of infringement is the same and that, under the circumstances, the defendant in this case had not established thát the use of his mark was not such as to lead to the belief that his goods were not goods manufactured or selected by the proprietors of the registered mark.

It may be argued indeed that the real meaning of registration on the supplemental register is this:

a. To place on record marks of category (e) of Section 2. It will be recalled, indeed, that Section 23 excludes from registration on the supplemental register marks of subsections (a), (b), and (d) of Section 2. In other words, registration will be granted on the supplemental register of marks which may be merely descriptive, words which are primarily geographical terms, and words which are primarily merely surnames. These three categories of marks may be admitted to registration on the supplemental register if they are capable of distinguishing the applicant's goods. One could urge in this connection an interpretation which is essentially

${ }^{10} \mathrm{Id}$. at $\$ 10$.

${ }^{20} 51$ Rep. Pat. Cas. 129 (1934). 
this: the definition of registrability on the principal register is that the mark must "identify the applicant's goods and distinguish them from those manufactured by others." The definition of a mark registrable on the supplemental register is that it must be "capable of distinguishing the applicant's goods." The difference is that marks registrable on the supplemental register are not capable, per se, of identifying the goods of the applicant because the mark, for instance, is primarily descriptive, or primarily geographical, or primarily a surname. But if such mark is used exclusively by the applicant it may be capable of distinguishing his goods. The declaration, called for by the rules, to be filed by an applicant for registration on the supplemental register is identical with the declaration for registration on the principal register in this: the applicant must state that "no other person to the best of his knowledge and belief has the right to use such mark in commerce." Thus, although Section 23 does not in terms speak of exclusive use by the applicant (the words used are: "which have been in lawful use in commerce by the proprietor thereof"), this is doubtless the meaning of the Act.

b. To place on record marks which do not fit the definition of a trade-mark under Section 45, i.e., which are not a word, name, symbol, or device or combination thereof. This definition is merely our traditional conception of a technical trademark under our common law. The Act provides for registration on the supplemental register of such marks as labels, packages, slogans, numerals, and combinations thereof. Our common-law theory is that these marks were protected under the law of unfair competition wherever it could be shown that they had acquired a secondary meaning, i.e., had come to identify the claimant's goods. The intention of the legislature was to place these marks on the register in advance of their having achieved the status of secondary-meaning marks and with the expectation that if their use is continued they may achieve such status.

c. It follows from the above that, if this status has in fact been reached, such marks may be placed on the principal register under Section $2(\mathrm{f})$.

It is submitted that the interpretation that Section $2(\mathfrak{f})$ must be deemed to apply only to "trade-marks" as defined in Section 45 and not to marks as defined in Section 23 should not be insisted upon, for the following two reasons-one of technical interpretation and one of general legislative intent:

a. While it is true that Section 2 begins with the words "No trade mark by which the goods of the applicants may be distinguished ...," the provisions of the section are made equally applicable to service marks, collective marks, and certification marks by the language of Sections $3^{21}$ and $4 .{ }^{22}$ Furthermore, it is not only subsection (f) of Section 2 that uses the word "mark." "Mark" rather than "trademark" is also used in subsections (d) and (e). "Mark" is defined in Section 45 as including, but not limited to, any trade-mark, service mark, collective mark, or certification mark, whether registered or not. Thus a package, even though it may

\footnotetext{
${ }^{21} 60$ Stat. 429, I5 U. S. C. $\$ 1053$ (1946).

2260 STAT. 429 , 15 U. S. C. \$ro54 (1946).
} 
not be a "device" within the meaning of the definition of "trade-mark," if it is capable of distinguishing, is a "mark" registrable under Section 23. Now the rule of Section $27^{23}$ is absolute, general, and without limitation: "Registration of a mark on the Supplemental Register shall not preclude registration by the registrant on the Principal Register." It would not seem that we are warranted in reading any limitation into this general rule of the Act. In other words, Section $2(f)$ must be read in the light of the general rule of Section 27.

b. It is clearly apparent from the legislative history of the Act that one of the underlying purposes was to make registrable all marks protectable at common law. If the intent of the Act is to be realized, marks of the category we are discussing must be registrable in the same manner and with the same effect as are words, symbols, pictures, etc.

No justifiable policy would be served by a different interpretation. There is no reason why a mark which has reached the status of a secondary-meaning mark should not go on the principal register, whether such mark is a trade-mark in the narrow, technical sense or in the broad sense of the law of unfair competition. This is precisely what the British law is; any mark registered in Part B of the register may be re-registered in Part A if it has, in fact, become distinctive of the goods of the applicant.

While it is urged that the above submissions are a proper interpretation of supplemental-register registrations, it is also believed that this may be a way of properly complying with the stipulation of Article 6 of the Convention. Indeed, we may thus enable an American applicant in a foreign country who seeks to register there a trade-mark based on registration in the supplemental register to say that his mark is a mark of a special category under the law of the United States, which is only provisionally on the supplemental register. Likewise, to a French applicant who protests that his bottle mark, if admitted to registration only on the supplemental register, is not duly protected, we may state that such registration gives it the status of a registered trade-mark.

\section{Protection of Prior User Rights}

Article 6 bis of the Convention provides that a foreign owner's trade-mark, well known in the country, shall be protected against registration of an infringing mark provided cancellation proceedings are filed within three years from the date of the infringing registration, or at any time in case of fraud. The stipulation is carried out by Section $\mathrm{I}_{4}^{24}$ of our Act.

\section{User of Foreign Trade-Marks}

Article 5 of the International Convention provides that, if in a certain country the use of a registered trade-mark is compulsory, the registration cannot be cancelled except after an equitable term and provided the interested party does not justify

${ }^{23} 60$ STAT. 436, I5 U. S. C. $\$ 1095$ (1946).

24 6o STAT. 433 , I5 U. S. C. $\$ 1064$ (1946). 
his non-user. This stipulation is carried out by the Act, in so far as Section $8^{25}$ is concerned, which requires an affidavit of use or justifiable non-use next preceding the expiration of six years from registration or publication under Section $12(c){ }^{2 b}$ There is some difficulty with Section $9{ }^{27}$ because the provisions for the filing of an affidavit under this section do not allow excuse of non-user as Section 8 does. In other words, when a foreign applicant files an application for renewal he must necessarily show by an affidavit that his mark is still in use in commerce. He cannot submit an affidavit excusing his non-user. Yet Article 5 of the International Convention says that the owner of a mark may always justify his non-user.

It is thought that "still in use" means use at the time of making the affidavit. The foreign applicant may well have been prevented for some time from using his mark in commerce with the United States, for instance, because of prohibition of exports of the particular products from the foreign country. Article 5 of the Convention purports to protect the registrant particularly in such cases. Foreign laws provide in such cases for an excuse of force majeur. If such excuse is not to be read in the provision of Section 9, the foreign trade-mark owner's only way out is to make a nominal shipment to the United States in order to be able to make the affidavit.

\section{Independence of Trade-Mark Rights}

Subsection $(f)$ carries out the stipulation of Article $6(D)$ of the International Convention, which provides that, when a mark has been duly registered in the country of origin and then in other countries, it shall be independent of the mark in the country of origin, provided it conforms to the national law of the particular country. This is precisely what subsection ( $f$ ) provides.

\section{Assignments and Licenses}

The Convention contains provisions on assignment of trade-marks and use by related companies. Article 6 quater has a limited effect only. It provides that the transfer of the trade-mark with the good will in the particular country will suffice, and it is not necessary to transfer the good will in the country of origin or other countries. This has always been so under our law, and certainly Section ro of the Lanham Act removes any doubt as to the position. The provisions of the Convention on use of trade-marks by related persons in Article 5(c)(3) authorize the simultaneous use of trade-marks by related establishments provided such use does not result in misleading the public and is not contrary to public interest. Section 5 of the Lanham Act is thoroughly in agreement with this stipulation.

There are other stipulations of the Convention which are carried out by the Lanham Act, such as Article 7 bis providing for the registration of association trade-marks, Article 8 for the protection of trade or commercial names, and Article to bis for protection against acts of unfair competition. Subsections (g) and (h) of

\footnotetext{
25 60 Stat. 431, 15 U. S. C. \$1058 (1946).

${ }^{26} 60$ STAT. 432 , 15 U. S. C. $\$ 1062$ (1946).

${ }^{27} 60$ STAT. 43I, I5 U. S. C. \$ro59 (1946).
} 
Section 44 carry out the provisions of the Convention on trade names and unfair competition. Also, we may mention here that Sections $42^{28}$ and $43^{29}$ of the Lanham Act carry out the provisions of Articles 9 and ro of the Convention for prohibition of importation of goods bearing infringing marks or names, or false designations of origin.

One cannot over-emphasize the significance of subsections (h) and (i) of Section 44 from the point of view of unfair competition law enforceable by the federal courts. I fully share the view expressed by Edward S. Rogers that the Lanham Act, by virtue of these provisions, has changed the situation created by Erie Railroad $v$. Tompkins. ${ }^{30}$ These provisions have the effect of placing trade names and unfair competition under federal control when in commerce within the control of Congress. I submit that this could be done directly in so far as interstate commerce is concerned, and it may be done thus indirectly in a provision extending rights to foreigners and then securing the same benefits to American citizens and residents as to foreigners.

One final remark on the relations between the Lanham Act and international conventions. Our constitutional rule is clear that treaties and acts of Congress (made in pursuance to the Constitution) are equally the supreme law of the land, that the courts are bound to enforce them, and that as between a treaty and an act of Congress the later in time prevails. Accordingly, if there is a clear conflict between an earlier treaty and a subsequent statute, it is the statute that prevails. However, the courts have said that a clear intent of Congress to "abrogate" the treaty is required before the courts will disregard a treaty stipulation. ${ }^{31}$ There is otherwise a presumption against the existence of a conflict between provisions of a statute and stipulations of a treaty.

In the case of the Lanham Act, the evidence is overwhelming that the object of Congress was to effectuate the stipulations of the conventions. Under the circumstances, it seems to me that whenever we are confronted with two possible interpretations of a provision of the Lanham Act, we must choose the one which will give effect to the International Convention rather than that which contravenes its stipulations.

On the other hand, should the United States adhere to future treaties or should the existing conventions be revised so as to incorporate stipulations which are not in agreement with the Lanham Act, the conclusion must be, under the same principle, that the convention must prevail so far as its provisions are such that they contain a rule of law enforceable by the courts. Any doubt as to this may now be deemed to have been set at rest by the decision of the Supreme Court in Bacardi v. Domenech in $1940^{32}$

\footnotetext{
${ }^{29} 60$ STAT. 440 , I5 U. S. C. \$II24 (1946).

${ }^{30} 60$ Stat. 44 r, 15 U. S. C. \$II25 (I946).

${ }^{30} 304$ U. S. 64 (1938).

32 Cook v. United States, 288 U. S. 102, 120 (r933).

s2 3 II U. S. I50 (I940).
} 
III

The Lanham Act also contains a number of provisions calculated to assist in the protection of American trade-marks abroad, but also embodies requirements which are not so calculated. It is of interest to refer to these.

One of the main problems confronting American trade-marks in foreign trade is that there is no protection for unregistered trade-marks abroad as we know it under our common law. Trade-mark infringement exists only with respect to registered trade-marks. This does not mean that the owner of an unregistered mark has no protection at all. He may sue for passing off in British countries and for unfair competition in a number of civil law countries. But this form of protection has distinct limitations.

The principle of the law of passing off in British countries is that no person shall falsely represent that his goods and his business are the same as the goods and the business of another. The issue, then, is whether the defendant's misrepresentation is such as is likely to deceive or mislead the public into believing that his goods and his business are those of the plaintiff when they are not. The plaintiff not only must establish his title to the trade-mark by adducing evidence of prior use, but he must also show public use of the mark for such time and in such manner that the goods have become known in the market by such mark. The onus is also on him to prove that the use by the defendant is likely to enable him to pass off his goods as those of the plaintiff. In other words, it is not enough for the plaintiff to show unauthorized use of his mark by the defendant because such use, per se, does not prove that the defendant is passing off. British courts may find, in a case where the mark of the plaintiff is not well known in the market and where the defendant has clearly shown his own origin of the products by affixing his name to the goods, that there is no likelihood of passing off.

In civil law countries, particularly in Europe, there is available unfair competition law protection. However, we must distinguish between two groups of such countries: those which have a broad law of unfair competition like our own and those which have special legislation on the suppression of certain acts of unfair competition. In the first category belongs particularly France, where the courts have built up with remarkable adaptability through the years a full body of unfair competion law which is case law like ours, based on a single Article of the Civil Code, Article 1382, which provides that a person shall be liable for all damage caused to another by his acts, or his negligence or imprudence. Equivalent provisions exist in the Belgian, Italian, Dutch, and Swiss civil codes, and a body of case law on unfair competition has been developed, although it is not complete in some of these countries, particularly in Italy.

Germany and other countries in Europe, including Austria, Hungary, Greece, Czechoslovakia, Denmark, Sweden, Norway, and Spain, have adopted special legislative acts for the suppression of unfair competition. - In many of these acts 
there is no general rule such as exists, for instance, in the German unfair competition law of I909, prohibiting any acts of competition contrary to honest practices. The act enumerates specific acts of deceptive or unfair conduct, such as unfair advertising, interference with contracts, discrediting the goods or business of a competitor, acts causing confusion with the name of another, copying labels or packages, etc., which are specifically prohibited.

In other words, in these countries there are in effect two different compartments of law-one for trade-marks and another for unfair competition. This is contrary to our conception of the trade-mark law as being part of the broader unfair competition law. The result is that trade-marks themselves are only protected against infringement or misappropriation under the trade-mark registration act, while other acts of unfair competition are protected by the special acts.

We have been considering the position of the owner of an unregistered trade-mark seeking protection against infringement by another. Suppose, however, the second person not only uses or imitates the unregistered trade-mark of the prior user, but also applies for registration of such mark in his own name, or obtains such registration. What are the rights of the prior user who may wish to oppose such application or to cancel the registration of the infringing mark?

On this point we have a great variety of foreign laws, but we can conveniently group them as follows:

I. In British countries generally, prior use enables cancellation of an infringing registration or opposition against an application for an infringing mark. It should be noted, however, that a registration in such countries becomes conclusive after five to seven years (depending on the country), so that if no action is taken to cancel such an infringing registration within this term, the prior user is ordinarily without remedy.

2. In the following countries, there is no opposition procedure; so that prior use, though recognized, cannot be availed of before the patent office, and the prior user must bring court proceedings, which may be costly and lengthy if the defendant puts up a defense:

$\begin{array}{lll}\text { Austria } & \text { France } & \text { Norway } \\ \text { Belgium } & \text { Holland } & \text { Poland } \\ \text { Czechoslovakia } & \text { Hungary } & \text { Rumania } \\ \text { Denmark } & \text { Italy } & \text { Sweden } \\ \text { Dominican Republic } & \text { Jugoslavia } & \text { Switzerland } \\ \text { Dutch Guiana } & \text { Lebanon } & \text { Syria } \\ \text { Dutch East Indies } & \text { Tunis } & \text { Turkey } \\ \text { Dutch West Indies } & \text { Morocco } & \end{array}$

3. In the following countries, opposition procedure is available, but the law requires the prior user to meet special conditions in order to succeed in an opposition:

Brazil: The mark of the prior user must be well known to the trade. 
Chile: Prior use for more than a year is required of the opposer. 'Prior user has no right of cancellation.

Colombia: Prior use of three years is required.

Cuba: A prior user cannot oppose under the law. However, he can cancel an infringing registration within the term of four years by a Patent Office proceeding.

Japan: Opposer must show that the mark has been extensively used in the country and is well known to the trade.

Mexico: There is no opposition procedure. The prior user may institute cancellation before the Patent Office within three years from date of infringing registration.

Portugal: If prior use has continued for more than six months, and the prior user failed to apply for registration, he is disqualified from opposing.

4. In Spain a recent decree required that all trade-marks used to distinguish products of any nature should be registered before July $\mathrm{I}$, 1947 .

5. In Canada, the position is peculiar. The person who first used or made known the mark in Canada is required to register within six months. If he fails to do so, and another person with less than six months' use applies for registration, registration will be granted to him, rather than to the prior user, although he was the first applicant. It was held in Canada Crayon Co. v. Peacock Products ${ }^{33}$ that, in view of the prior user's failure to register, his prior use of the trade-mark was immaterial and the subsequent user's registration could not be disturbed on this ground. The case was followed recently in Fine Foods of Canada v. Metcalfe Foods. ${ }^{34}$ The Supreme Court of Canada has not yet passed on this question.

6. In the following countries the prior user may oppose pretty much the same as in the United States:

China

Egypt

Guatemala

\begin{abstract}
Nicaragua
\end{abstract}
Panama

Philippines
Puerto Rico

Uruguay

Venezuela

7. In the following countries prior use gives no rights against a prior applicant or registrant:

$\begin{array}{lll}\text { Argentina } & \text { Finland } & \text { Iran (Persia) } \\ \text { Bolivia } & \text { Germany } & \text { Peru } \\ \text { Bulgaria } & \text { Liberia } & \text { Salvador } \\ \text { Costa Rica } & \text { Haiti } & \text { U. S. S. R. } \\ \text { Ecuador } & \text { Paraguay } & \end{array}$

In view of the above condition of the law in foreign countries, it would seem important for our law to make it possible for trade-mark owners to register their trademarks in foreign countries in order to obtain protection.

${ }^{3 s}$ Ex. C. R. 178 (1932).

342 Fox. Pat. C. II3, 202 (1942). 
The Lanham Act purports to assist American trade-mark owners in registering abroad by the following provisions:

I. Section 23 provides that, upon a proper showing by the applicant that he has begun the lawful use of his mark in foreign commerce and that he requires domestic registration as a basis for foreign protection of his mark, the Commissioner may waive the requirement of a full year's use and may grant registration forthwith on the supplemental register.

2. Registrations existing under the Act of Ig2o expire six months after the effective date of the Act or twenty years from the date of registration, whichever date is later, under Section $46(\mathrm{~b}),{ }^{35}$ but renewal will be granted when required to support foreign registrations.

3. Under Section $30{ }^{36}$ the Commissioner may issue a single certificate for one mark registered in a plurality of classes. In countries where a certified copy of United States registration is required and a translation has to be made, and in countries where there is no classification of goods or the official classification is different from ours, this simple expedient may save considerable cost to the American applicant in a foreign country.

On the other hand, the Lanham Act provides in Section $25^{37}$ that the certificate of registration for marks registered on the supplemental register shall be conspicuously different from certificates on the principal register. This may involve unnecessary difficulties to American applicants presenting certificates of registration on the supplemental register in foreign countries, since some countries may refuse to give full credit to such registrations, as will be explained hereafter.

The most serious handicap to American trade-mark owners in registering their marks in foreign countries which has been maintained by the Lanham Act is the requirement that foreign applicants who have not used their marks in the United States must produce a certified copy of the registration of their mark in the country of origin. In most of the European countries, American nationals are required to produce certified copies of their registrations in the United States, because we make the same requirement of their nationals.

The requirement under our Act that foreigners produce a certified copy of their home registration is generally empty of any significance. In most of the European countries, nationals obtain registration as a matter of mere formality. They are not required to use a trade-mark before applying for registration.

On the other hand, the consequent requirement that American applicants produce a certified copy of United States registration is a very serious handicap for the following reasons:

I. European countries are generally more liberal in the registrability of trademarks. They do not prohibit the registration of surnames and geographical terms.

\footnotetext{
${ }^{35} 60$ STAT. 427 , 15 U. S. C. note following \$ro5T (1946).

${ }^{30} 60$ STAT. 436, I5 U. S. C. \$III2 (1946).

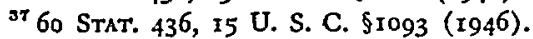


They accept for registration labels, packages, configurations of goods, slogans, and the like, all of which are registrable in the United States either on the supplemental register or under Section 2(f). American trade-mark owners generally will not desire to register on the supplemental register if there is any chance at all of obtaining registration on the principal register. They may also be reluctant to base their registration in the foreign country on a certificate in the supplemental register, especially since this is issued in a different form, which operates as a "red flag" in the foreign country and may invite an attack in the future on the ground that it is not a full-fledged registration.

2. In view of the time usually consumed in completion of a registration in the United States through the examination and opposition procedure, the American applicant ordinarily will not proceed with foreign applications on the basis of a certified copy of the application filed in the United States Patent Office within the Convention priority until he has obtained registration here. Then it may be too late, since the mark may in the meantime be misappropriated in the foreign country.

3. The American trade-mark owner may not be able to obtain registration in this country for reasons which have nothing to do with the foreign countries, and this again makes it impossible for the trade-mark owner to register in the foreign countries.

4. In a number of countries, the registration is dependent on the United States registration, so that its expiration or assignment in the United States forfeits the registration in the foreign country. Also, whenever the registration is renewed in the United States a certified copy of the renewal must be filed in a number of foreign countries, regardless of the term of the foreign registration.

5. Re-registration of a trade-mark in the United States on the principal register may not support the foreign registrations obtained on the basis of the earlier United States registration under the Acts of $188 \mathrm{I}$, I905 or 1920, so that the American owner must also maintain these old registrations.

6. The American owner may not be able to renew a registration under Section 9 because the form of the mark has been varied in the meantime; in such case the foreign registrations based on the original may be forfeited.

7. In view of the lack of unfair competition law protection in foreign countries, the American owner may wish to register his mark in such countries in a form different from that used in the United States (for instance, a label instead of a word mark, or with specific claim to colors, or for the foreign translation of his mark, or for a broader list of goods), and he may not do so because he is restricted to the form of mark and the coverage shown in the certified copy of his United States registration.

It is desirable that the Lanham Act be amended to permit foreign applicants to apply for registration of their trade-marks without submitting certified copies of 
home registration in order that our own nationals may avail themselves of the same advantage in foreign countries.

In the absence of such amendment, the question may be taken care of by an amendment of the International Convention specifically providing that persons entitled to its benefits are not required to produce certified copies of home registration. Such a stipulation would be self-executing in the United States and would supersede the requirement of the Lanham Act. 